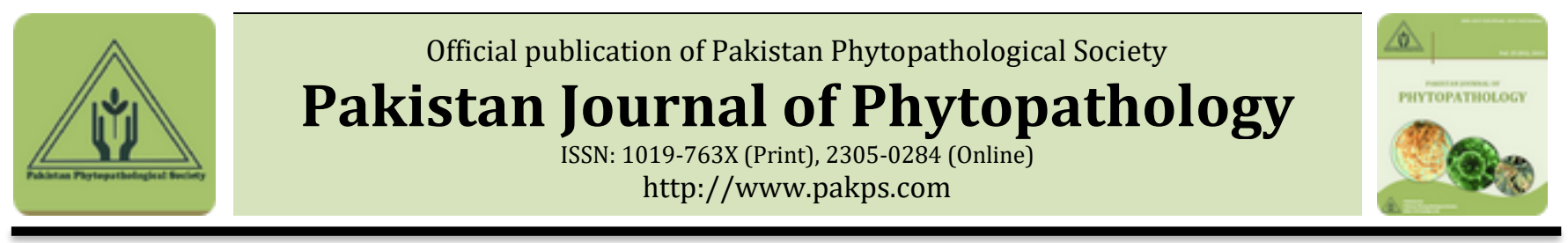

\title{
OCCURRENCE AND DISTRIBUTION OF VEGETABLES SEED-BORNE MYCOFLORA IN PUNJAB PAKISTAN
}

\author{
aBilal Ahmed, bBabar Khan, aMuhammad U. Ghazanfar, bNasir A. Rajput, bAmir Saleem, bAbdul Jabbar, \\ bWaqar Ahmed, bMadassar Walait \\ ${ }^{a}$ Department of Plant Pathology, University of Sargodha, Sargodha, Pakistan. \\ ${ }^{b}$ Department of Plant Pathology, University of Agriculture, Faisalabad, Pakistan.
}

\begin{abstract}
A B S T R A C T
Vegetable seeds are carrier of mycoflora inciting bulk of diseases, responsible for quality and yield losses. Majority of microbes are saprophyte and few are potential pathogen for the crop. In this research seed mycoflora were isolated by using standard blotter paper and agar plate technique. Major vegetables of summer and winter seeds were collected from regional local markets of Punjab province. Among these 15 fungal genera and 18 different species were identified. According to results highest incidence of fungal pathogens were Aspergillus niger, A. flavus, Penicillium camemberti and Bipolaris spp. and low incidence of Stemphylium spp., Cladosporim spp., F. semitectum, Curvularia lunata, Trichoderma spp., Rhizopus nigricans, Paecilomyces lilacinus, Fusarium oxysporum, Drechslera australiensis, Ascochyta spp., A. fumigatus, Rhizoctonia spp., Alternaria alternata and Chaetomium globosum. The agar plate method was found to be the most suitable technique for detection of seed-borne fungi in vegetable seed. The results of this study could be helpful for management of seed borne fungal pathogens of different vegetables. Our findings may also helpful for seed treatment before sowing with appropriate fungicides to overcome the losses caused by seed borne fungi.
\end{abstract}

Keywords: Saprophytes, Pathogenic, Detection, Isolation, Identification, Purification

\section{INTRODUCTION}

Vegetables are secondary food source of humans and rich source of nutrients, proteins, carbohydrates, minerals, fibers and vitamins essential for health (Sonni, 2002). In 2002-2003 vegetables are cultivated in Pakistan on an area of 0.22 million hectares which produce 2.88 million tons' vegetables. Exports of vegetables increased 39\% during physical year of 2007-2011. Climate of Pakistan is very suitable for production of different vegetables. Among different vegetables bitter gourd (Momordica charantia), sweet gourd (Cucurbita moschata), okra (Ablemochus esculentus), pumpkin (Cucurbita moschata), bottle gourd (Lagenaria siceraria) and squash (Cucurbita Submitted: October, 20, 2017

Revised: December, 19, 2017

Accepted for Publication: December 22, 2017

* Corresponding Author:

Email: babarkhan.uaf@gmail.com

(C) 2017 Pak. J. Phytopathol. All rights reserved. pepo) were broadly cultivated and in case of winter vegetables carrot (Daucus carrota var sativa), turnip (Brassica rapa) and reddish (Raphanus sativus) were most cultivated vegetables in Pakistan described by (Ali and Kumar, 2000).

In Pakistan depletion of healthy seeds is very alarming especially in Punjab region. The share of vegetables seed is $72 \%$ in the Punjab province. In Punjab different vegetables pea, summer squash, carrot, okra, chilies, potato, pumpkin, bitter gourd, turnip, cauliflower and bottle gourd which have great importance in Pakistan reported by (Bakhsh, 2007). Among different plant pathogen transporting agents' seeds are major contributors that covers long distances without any hurdle. The dispersal of diseases through seeds from one region to other region is well recognized (Agarwal and Sinclair, 1996). Seed-borne pathogens are involved in seed rottening during germination and seedling mortality leading to poor crop stand (Khalid et al., 2001), plant 
growth reduction and low yield of crops (Kubiak and Korbas, 1999; Dawson and Bateman, 2001). Due to contamination of seeds initiation of local infection that reduce the germination rate, abortion of seed, seed rot, stunted growth, viability, and permeability. The main root rotting fungi that cause heavy losses to crops are Phytophthora spp., Verticillium spp. Rhizoctonia spp., Pythium spp., and Phytophthora spp. The fungal attack increased due to poor storage that causes discoloration, decaying of seed and mycotoxin production (Logrieco et al., 2003). Thus in present study we concentrated on isolation, identification and purification of vegetables seed borne fungi existing in different districts of Punjab, Pakistan.

Table 1. Sources and localities for seed sam

\begin{tabular}{ll}
\hline Name of vegetable & Botanical name \\
\hline Bitter gourd & Momordica charantia \\
Bottle gourd & Lagenaria siceraria \\
Carrot & Daucus carrota var sativa \\
Cucumber & Cucumis sativus \\
Okra & Abelmochus esculentus \\
Pea & Pisum sativum \\
Pumpkin & Cucurbita moschata \\
Radish & Raphanus sativus \\
Summer squash & Cucurbita pepo \\
Turnip & Brassica rapa \\
\hline
\end{tabular}

Agar plate method: Potato dextrose agar medium was prepared for fungal growth and sterilized at $121^{\circ} \mathrm{C}$ for 20 minutes at 15 psi pressure. After sterilization media cooled until mild hot and poured $15 \mathrm{ml}$ in each Petri dish having $90 \mathrm{~cm}$ diameter. Seeds were surface sterilized with $1 \% \mathrm{NaOCl}$ solution one and half minute and give three washes in sterilized double distilled water. After surface sterilization seeds were placed in Petri dishes containing media and incubate at $22{ }^{\circ} \mathrm{C} \pm 1{ }^{\circ} \mathrm{C}$ for 5 to 7 days in an incubator. All processes were carried out under laminar flow chamber to maintain hygienic condition.

Standard blotter paper technique: Evaluation of seed borne mycoflora was done by using standard blotter paper technique. In this technique sterilized blotter paper was used in Petri dishes in spite of any medium. The 5-10 surface sterilized seeds were transferred in Petri dishes containing wet blotter paper in three layers and incubate at $25^{\circ} \mathrm{C}$ and maintain light and dark conditions (Anonymous, 1996). After germination of fungal mycoflora all fungal colonies were purified and observed under stereo microscope. The bud tip of each fungus was isolated and purified on other plates

\section{MATERIALS AND METHODS}

Collection of seed samples: The seed samples were collected according to their area of production from different local markets, corporations, seed stores and research centers from Punjab province during winter and summer 2013-15 (Table 1). All seeds were categorized and preserved in polythene bags and stored according to dispensing conferring method (Yuan et al., 1997). In each lot 400 seeds were separated and used to check the pathogen infection by using blotter paper and agar plate methods (ISTA, 1993). All experiments were conducted in Department of Plant Pathology research area University college of Agriculture Sargodha.

$\begin{array}{lll}\text { Family } & \text { Summer/winter } & \text { Place of collection } \\ \text { Cucurbitaceae } & \text { Summer } & \text { Bhakkar } \\ \text { Cucurbitaceae } & \text { Summer } & \text { Multan } \\ \text { Apiaceae } & \text { Winter } & \text { Vehari } \\ \text { Cucurbitaceae } & \text { Summer } & \text { Multan } \\ \text { Malvaceae } & \text { Summer } & \text { Mianwali } \\ \text { Fabaceae } & \text { Winter } & \text { Narrowal } \\ \text { Cucurbitaceae } & \text { Summer } & \text { Narowal } \\ \text { Brassicaceae } & \text { Winter } & \text { Sargodha } \\ \text { Cucurbitaceae } & \text { Summer } & \text { Chiniot } \\ \text { Brassicaceae } & \text { Winter } & \text { Sargodha }\end{array}$

containing media for further identification. Each fungus was identified according to their physical and morphological properties by using illustrated genera (Nelson et al., 1983; Booth, 1971; Raper and Fennel, 1965). All treatments were replicated three times. Percentage frequency of seed borne mycoflora was estimated by using formula:

$$
\text { Percentage mean frequency }=\frac{\text { No. of infected seed }}{\text { Total number of seed }} \times 100
$$

Isolation and purification of seed-borne mycoflora: Isolation was done on the basis of tissue symptoms to find out the association of specific mycoflora by taking hyphal bud tip or single spore from growing colony on seeds and purified on alternate Petri dishes containing PDA media.

Single spore technique: In case of single spore technique, serial dilutions of spore suspension from seven days old culture were made in sterilized distilled water until a solution containing 10-15 spores/ml was achieved. One $\mathrm{mL}$ of this diluted spore suspension was poured in Petri dish containing two percent plain agar autoclaved for 15 minutes under aseptic conditions. Spore suspension was evenly distributed by tilting the Petri plate in various directions. After few minutes, 
excess suspension was removed from Petri-dishes. Inoculated Petri dishes were incubated at $24 \pm 2^{\circ} \mathrm{C}$ for 24 hours. Germinating single spore was located and marked under the microscope and transferred on 2 percent PDA slants, aseptically. Inoculated slants were subsequently allowed to grow and sporulate.

Hyphal tip method: The method is same as described previous except that in its place of single spore, hyphal tip was marked and transferred on two per cent PDA slants.

Identification: Identification of isolated fungi was done by using synoptic key (Mathur and Kongsdal, 2003).

Table 2. Identification of all isolated fungi on the basis of Morphology

\begin{tabular}{|c|c|c|c|}
\hline Fungi Name & Colony colour/Shape & Spore /Conidia & Hyphal stucture \\
\hline Aspergillus niger & $\begin{array}{l}\text { Date brown with white to cream thick } \\
\text { mat of floccose mycelia at the edge }\end{array}$ & $\begin{array}{l}\text { Conidia were biseriate } \\
\text { and globose in shape }\end{array}$ & Fusiform shaped \\
\hline A. fumigatus & Greenish grey with colorless mycelia & Rod shaped conidia & Filamentous hyphae \\
\hline A. flavus & $\begin{array}{l}\text { Yellow green with white mycelia at the } \\
\text { edges }\end{array}$ & The conidia were rough & $\begin{array}{l}\text { Septate and hyaline with } \\
\text { thread like branching }\end{array}$ \\
\hline $\begin{array}{l}\text { Alternaria } \\
\text { alternata }\end{array}$ & Colonies were brown segmented mycelia & Solitary apical spores & Muriform shaped hypahe \\
\hline Bipolaris spp. & $\begin{array}{l}\text { Black, velvet colonies and mycelium } \\
\text { practically absent }\end{array}$ & Black and shiny conidia & Hyaline and pseudosepta \\
\hline $\begin{array}{l}\text { Chaetomium } \\
\text { globosum }\end{array}$ & $\begin{array}{l}\text { Colonies were cottony appearance with } \\
\text { brown to blackish mycelium }\end{array}$ & Unidentifiable conidia & Football shaped \\
\hline $\begin{array}{l}\text { Cladosporim } \\
\text { spp. }\end{array}$ & Long, branching filamentous structure & $\begin{array}{l}\text { Ovoid, oblong, spherical } \\
\text { and lemon-shaped }\end{array}$ & Long filamentous \\
\hline $\begin{array}{l}\text { Fusarium } \\
\text { oxysporum }\end{array}$ & $\begin{array}{l}\text { White to purple mycelium with distinct } \\
\text { orange sporodochia }\end{array}$ & Smooth or rough walled & $\begin{array}{l}\text { Fusiform, slightly curved } \\
\text { and pointed at the tip }\end{array}$ \\
\hline F. semitectum & Mostly straight with aerial mycelium & Simple or branched & Hyaline and septate \\
\hline $\begin{array}{l}\text { Paecilomyces } \\
\text { lilacinus }\end{array}$ & $\begin{array}{l}\text { Colonies were faint violet or mauve } \\
\text { colouration which may change into a } \\
\text { reddish grey colour }\end{array}$ & Long chain conidia & $\begin{array}{l}\text { Hyaline and smooth walled } \\
\text { hyphae }\end{array}$ \\
\hline $\begin{array}{l}\text { Penicillium } \\
\text { camemberti }\end{array}$ & $\begin{array}{l}\text { Colonies form a hard, white crust } \\
\text { structures of mycelium }\end{array}$ & Rough and smooth & Thread-like hyphae \\
\hline Rhizoctonia spp. & $\begin{array}{l}\text { At initial stage colonies were colorless } \\
\text { but become brown at maturity }\end{array}$ & Irregular shaped & Separated hyphae \\
\hline $\begin{array}{l}\text { Rhizopus } \\
\text { nigricans }\end{array}$ & $\begin{array}{l}\text { A unicellular to a dimorphic or } \\
\text { filamentous appearance }\end{array}$ & Unidentifiable conidia & $\begin{array}{l}\text { Filamentous, branching and } \\
\text { generally lack cross walls }\end{array}$ \\
\hline $\begin{array}{l}\text { Stemphylium } \\
\text { spp. }\end{array}$ & $\begin{array}{l}\text { Colonies were brownish to black in color } \\
\text { with suede to cottony surface }\end{array}$ & $\begin{array}{l}\text { Spore has a transverse } \\
\text { septation }\end{array}$ & Dematiaceous hyphae \\
\hline $\begin{array}{l}\text { Trichoderma } \\
\text { spp. }\end{array}$ & $\begin{array}{l}\text { Colonies were transparent or whitish in } \\
\text { colour }\end{array}$ & Compact or loose tufts & Highly branched \\
\hline $\begin{array}{l}\text { Curvularia } \\
\text { lunata }\end{array}$ & $\begin{array}{l}\text { Colonies were brown to black colour, } \\
\text { hairy, velvety or woolly in shape }\end{array}$ & Smooth texture conidia & $\begin{array}{l}3 \text { septa and } 4 \text { cells with } \\
\text { curved appearance }\end{array}$ \\
\hline $\begin{array}{l}\text { Drechslera } \\
\text { australiensis }\end{array}$ & $\begin{array}{l}\text { A gray to dark blackish brown colour } \\
\text { mycelium }\end{array}$ & Straight or cylindrical & $\begin{array}{l}\text { Solitary, flexible and } \\
\text { septate }\end{array}$ \\
\hline Ascochyta spp. & Brown to black colour mycelium & Pear shaped conidia & Varied shaped \\
\hline $\begin{array}{l}\text { Results showe } \\
\text { dominance of } \\
\text { spp., Aspergillus }\end{array}$ & $\begin{array}{l}\text { hat both techniques confirmed the } \\
\text { rophytic fungi which were Rhizopus } \\
\text { p., Curvularia spp., Penicillium spp. and }\end{array}$ & \multicolumn{2}{|c|}{$\begin{array}{l}\text { Chaetomium spp. The plant pathogenic fungi Drechslera } \\
\text { spp., Bipolaris spp., Macrophomina spp., Ascochyta spp. } \\
\text { and Fusarium spp were also dominant in few seeds. }\end{array}$} \\
\hline
\end{tabular}


General prevalence of fungi was as following in the table.

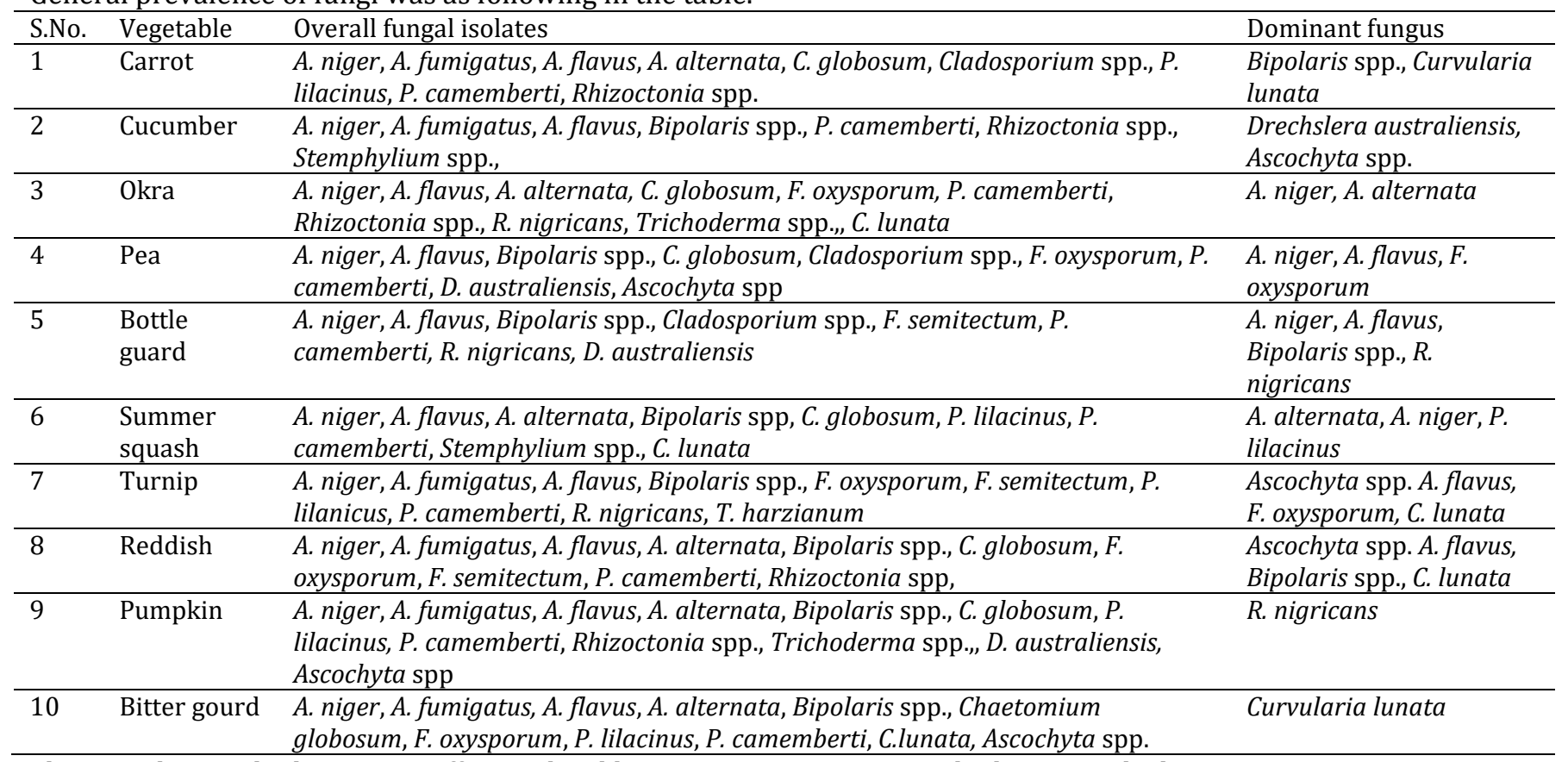

The agar plate method was more affective then blotter paper proven methods. Due to high nutrient concentrations PDA method. In agar plate method fungal growth is higher than blotter paper and separation of different fungi on the base of morphology was easy than blotter paper method. Very high growth difference observed between these two scientifically medium boost the growth of fungal pathogen than blotter paper and highest fungal growth was at $25^{\circ} \mathrm{C}$. In agar plate method total isolates production were higher than blotter isolation technique (Table 3 and 4).

Table 3. Mycoflora of different vegetables seeds by using blotter paper method. Bi. G = Bitter gourd, Bo. G = Bottle gourd, Ca $=$ Carrot, $\mathrm{Cu}=$ Cucumber, $\mathrm{O}=$ Okra, $\mathrm{Pe}=\mathrm{Pea}, \mathrm{Pu}=$ Pumpkin, $\mathrm{R}=$ Reddish, $\mathrm{S} . \mathrm{S}=$ Summer squash and $\mathrm{T}=\mathrm{Turnip}$.

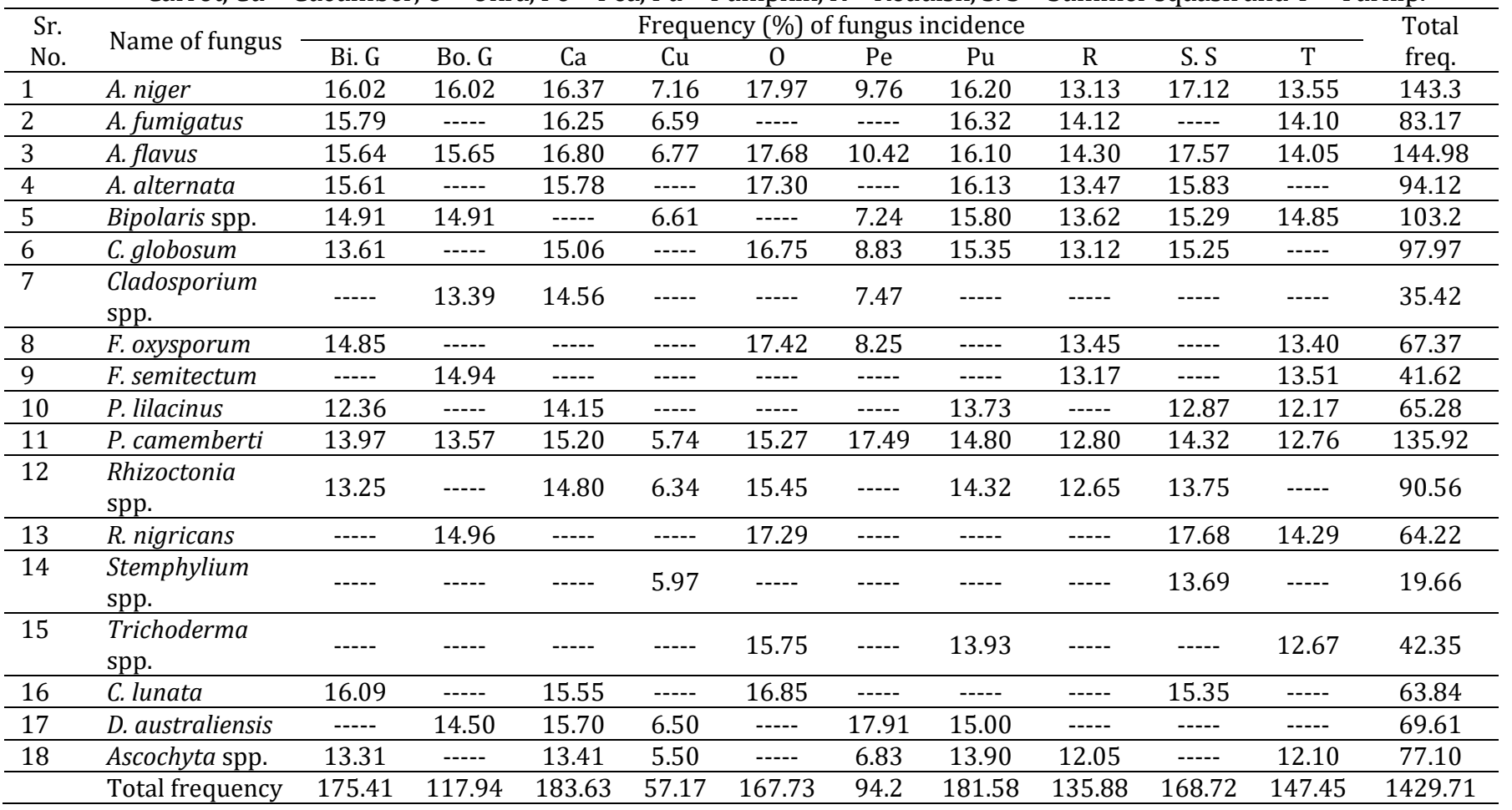


Pak. J. Phytopathol., Vol. 29 (02) 2017. 265-271

Table 4. Mycoflora of different vegetables seeds by using agar plate method. Bi. G = Bitter gourd, Bo. G = Bottle gourd, $\mathrm{Ca}=$ Carrot, $\mathrm{Cu}=$ Cucumber, $\mathrm{O}=$ Okra, $\mathrm{Pe}=\mathrm{Pea}, \mathrm{Pu}=$ Pumpkin, $\mathrm{R}=$ Reddish, $\mathrm{S} . \mathrm{S}=$ Summer squash and $\mathrm{T}=$ Turnip.

\begin{tabular}{|c|c|c|c|c|c|c|c|c|c|c|c|c|}
\hline \multirow{2}{*}{$\begin{array}{l}\text { Sr. } \\
\text { No. }\end{array}$} & \multirow{2}{*}{ Name of fungus } & \multicolumn{10}{|c|}{ Frequency (\%) of fungus incidence } & \multirow{2}{*}{$\begin{array}{l}\text { Total } \\
\text { freq. }\end{array}$} \\
\hline & & Bi. G & Bo. G & $\mathrm{Ca}$ & $\mathrm{Cu}$ & 0 & $\mathrm{Pe}$ & $\mathrm{Pu}$ & $\mathrm{R}$ & S.S & $\mathrm{T}$ & \\
\hline 1 & A. niger & 23.26 & 21.08 & 22.60 & 27.59 & 24.45 & 24.25 & 20.54 & 17.32 & 8.62 & 16.12 & 205.83 \\
\hline 2 & A. fumigatus & 23.10 & $-\ldots$ & 23.20 & 28.48 & $-\cdots-$ & $-\cdots-$ & 22.70 & 15.08 & ----- & 18.06 & 130.62 \\
\hline 3 & A. flavus & 22.92 & 22.92 & 22.15 & 26.77 & 13.41 & 22.15 & 22.93 & 16.03 & 7.62 & 17.91 & 194.81 \\
\hline 4 & A. alternata & 20.80 & $-\ldots--$ & 19.70 & $-\cdots---$ & 13.40 & --.-- & 21.06 & 13.35 & 8.46 & --.-- & 96.77 \\
\hline 5 & Bipolaris spp. & 22.59 & 22.92 & ---- & 25.55 & $-\cdots$ & 20.23 & 21.65 & 14.09 & 8.40 & 15.74 & 151.17 \\
\hline 6 & globosum & 21.64 & --.- & 17.58 & - - & 10.35 & 17.57 & 20.85 & 14.32 & 7.05 & $-\cdots$ & 109.36 \\
\hline 7 & $\begin{array}{l}\text { Cladosporium } \\
\text { spp. }\end{array}$ & ---- & 21.24 & 11.38 & $-\cdots--$ & $-\cdots--$ & 11.38 & ----- & $-\cdots--$ & ---- & ---- & 44.00 \\
\hline 8 & F. охуsporum & 23.22 & $-\cdots$ & $-\cdots$ & $-\cdots$ & 12.03 & 20.97 & $-\cdots$ & 15.31 & $\begin{array}{l}---- \\
-1\end{array}$ & 17.87 & 89.4 \\
\hline 9 & F. semitectum & ---- & 22.91 & $-\cdots--$ & ---- & ----- & ---- & ----- & 14.28 & $-\cdots--$ & 16.92 & 54.11 \\
\hline 10 & P. lilacinus & 18.80 & --.-- & 13.65 & $-\cdots$ & --.-- & -..-- & 19.83 & $-\cdots$ & 5.91 & 13.98 & 72.17 \\
\hline 11 & P. camemberti & 22.15 & 22.15 & 14.43 & 26.93 & 12.37 & 14.43 & 20.55 & 15.12 & 7.48 & 14.59 & 170.2 \\
\hline 12 & $\begin{array}{l}\text { Rhizoctonia } \\
\text { spp. }\end{array}$ & 21.58 & ----- & 13.78 & 25.04 & 12.20 & ---- & 20.30 & 13.47 & 9.19 & ---- & 115.56 \\
\hline 13 & R. nigricans & $-\cdots--$ & 25.18 & $-\cdots--$ & $-\cdots--$ & 12.62 & $-\cdots--$ & $-\cdots-$ & $-\cdots--$ & 8.07 & 17.36 & 63.23 \\
\hline 14 & $\begin{array}{l}\text { Stemphylium } \\
\text { spp. }\end{array}$ & ----- & ---- &.-- & 22.60 & ---- & - & ----- & ---- & 6.14 & ---- & 28.74 \\
\hline 15 & $\begin{array}{l}\text { Trichoderma } \\
\text { spp. }\end{array}$ & ----- & ---- & -- & ---- & 11.22 & ---- & 20.27 & ---- & ---- & 16.49 & 47.98 \\
\hline 16 & C. lunata & 22.53 & ---- & 22.13 & $-\cdots$ & 12.85 & $-\cdots$ & $-\cdots$ & ---- & 9.27 & $-\cdots$ & 66.78 \\
\hline 17 & D. australiensis & ---- & 22.48 & 17.70 & 25.90 & $-\cdots$ & 17.70 & 20.95 & ---- & ---- & $-\cdots$ & 104.73 \\
\hline 18 & Ascochyta spp. & 16.29 & $-\cdots$ & 12.53 & 23.68 & ---- & 12.53 & 20.05 & 12.85 & $\begin{array}{ll}---- \\
-1\end{array}$ & 13.07 & 111.00 \\
\hline & Total frequency & 258.88 & 180.88 & 211.33 & 232.54 & 134.9 & 161.21 & 251.68 & 161.22 & 86.21 & 178.11 & 1856.96 \\
\hline
\end{tabular}

\section{DISCUSSION}

Many fungal pathogens affect the vegetables production specially cucurbits (Abawi and Widmer, 2000). Pathogens cause various diseases such as Wilt, Rot, Damping off, Anthracnose, Phomopsis black stem, Phoma blight, Scab, Gummy stem blight, Downy mildew, Powdery mildews, Leaf spot and Leaf blight (Zitter et al., 1996; Koike et al., 2006). Seed is the first foundation brick for crop production. Healthy seed is a basic need to maintain and achieve plant populations for maximum yield. Among 16\% annual crop losses, plant diseases were recognized as $10 \%$ and major contributor is contaminated seed (Fakir, 1983). In previous studies 15 genera and 29 fungal species were isolated from bitter gourd seeds in Pakistan using ISTA techniques (Sultana and Ghaffar, 2007).

Several seed borne fungi prevail on cucurbits including: Botryodiplodia theobromae, A. alternata, C. lunata, Chaetomium spp., D. tetramera, F. equiseti, F. solani and F. moniliforme on gourd seeds and on squash, watermelon, bitter gourd muskmelon and cucumber (Nair, 1982; Mathur, 1990). Several studies also reveal that rice seeds also infected with seed borne fungi (Khan et al., 1988). In cucurbits blotter method was useful for detection of most infectious fungi (Begum and Momin, 2000; Elwakil and El-Metwally, 2001; Avinash and Ravishankar, 2013). Squash seed results confirm the previous recorded results in Pakistan (Rahim et al., 2013). It is supposed due to the plenty of nutritional elements essential for fungal growth in the agar plate method. Soybean seeds infested with Alternaria, Curvularia and Fusarium coupled with isolation of Aspergillus spp. and Penicillium spp. were commonly found. These fungi cause seed bio deterioration of soybean seed (Chavan, 2011). The seed borne fungi reduce the germination rate, oil contents, carbohydrate, and protein; manipulate other biochemical changes in grains (Ijaz et al., 2001). Fat and protein contents were reduced by $A$. flavus, $A$. terreus, $A$. nigar, A. fumigates, $A$. versicolor reduced the sugar contents (Chavan, 2011). The production of aflatoxin due to Fusarium spp. infestation cause devastative impact on seed germination and health (Ozcelik et al., 1990; Frisvad and Thrane, 2004). Fusarium species are mostly seed borne or soil borne which cause root rot and damage seedlings and seeds (Anjorin et al., 2008; Liu et al., 2012). Generally, Rhizoctonia, Phytopathora, Pythium and Fusarium spp. under suitable environmental conditions cause seedling death and also kill the seeds before germination (Leslie et al., 2005; Broders et al., 2007). Our findings provide the base for seed handling 
before sowing. The relationship of these saprotrophic and pathogenic fungi is well established according to previous reports (Fakhrunnisa and Ghaffar, 2006; Niaz and Dawar, 2009). Our findings also endorse the previous reports.

\section{CONCLUSION}

This effort provides the availability of seed standard in our markets that is very alarming. It is proved that seeds of vegetables are contaminated with different soil borne fungi that cause severe losses. Plant pathogenic fungi are prevailing in seeds and that ultimately transferred in farmer's fields which cause fields which cause losses in the form of poor germination and early disease spread. There is a big requirement to screen the seeds for healthy crop and maximum yield.

\section{REFERENCES}

Abawi, G. S. and T. L. Widmer. 2000. Impact of soil health management practices on soilborne pathogens, nematodes and root diseases of vegetable crops. Applied Soil Ecology, 15: 37-47.

Agarwal, V. K. and J. B. Sinclair. 1996. Principles of seed pathology. CRC Press.

Ali, M. and S. Kumar. 2000. Problems and prospects of pulses research in India. Indian Farm, 50: 4-13.

Anjorin, S. and M. Mohammed. 2009. Effects of seedborne fungi on germination and seedling growth of watermelon (Citrullus lanatus). Journal of Agriculture and Social Sciences, 5: 77-80.

Association, I. S. T. 1993. Intermediate rules for seed testing. Seed Science and Technology, 21: 37-41.

Avinash, T. and V. RavishankarRai. 2013. Identification of diverse fungi related with selected cucurbitaceae vegetables. Journal of Agricultural Technology, 9: 1837-1848.

Bakhsh, K. 2007. An analysis of technical efficiency and profitability of growing potato, carrot, radish and bitter gourd: A case study of Pakistani Punjab. Unpublished Ph. D. Dissertation, Department of Farm Management, University of Agriculture, Faisalabad, Pakistan.

Begum, H. and A. Momin. 2000. Comparison between two detection techniques of seed-borne pathogens in cucurbits in Bangladesh. Pakistan Journal of Scientific and Industrial Research, 43: 244-248.

Booth, C. 1971. Chapter II Fungal Culture Media. Methods in Microbiology. Elsevier, pp. 49-94.

Broders, K. D., P. E. Lipps, P. A. Paul and A. E. Dorrance. 2007. Evaluation of Fusarium graminearum
Associated with Corn and Soybean Seed and Seedling Disease in Ohio. Plant Disease, 91: 11551160.

Chavan, A. M. 2011. Nutritional changes in oilseeds due to Aspergillus spp. Journal of Experimental Sciences, 2.

Dawson, W. A. J. M. and G. L. Bateman. 2001. Fungal communities on roots of wheat and barley and effects of seed treatments containing fluquinconazole applied to control take-all. Plant Pathology, 50: 75-82.

Elwakil, M. A. and M. A. El-Metwally. 2001. Seed-Borne Fungi of Peanut in Egypt: Pathogenicity and Transmission. Pakistan Journal of Biological Sciences, 4: 63-68.

Fakhrunnisa, M. H. and A. Ghaffar. 2006. In vitro interaction of Fusarium spp., with other fungi. Pakistan Journal of Botany, 38: 1317-1322.

Fakir, G. 1983. Teaching, training and research activities of seed pathology in Bangladesh. Seed Science and Technology.

Frisvad, J. C. and R. A. Samson. 2004. Polyphasic taxonomy of Penicillium subgenus Penicillium. A guide to identification of food and air-borne terverticillate Penicillia and their mycotoxins. Studies in mycology, 49: C174.

Ijaz, A., S. Anwar, A. Riaz and M. Khan. 2001. Seed borne pathogens associated with wheat seed and their role in poor germination. Pakistan Journal of Phytopathology, 13: 102-106.

Khan, S., A. Khanzada, S. Nasreen and M. Aslam. 1988. Evaluation of seed health testing techniques for the assessment of seed-borne mycoflora of rice. Pakistan Journal of Agricultural Research, 9: 502505.

Koike, S. T., P. Gladders and A. Paulus. 2006. Vegetable diseases: A colour handbook. CRC Press.

Kubiak, K. and M. Korbas. 1999. Occurrence of fungal diseases on selected winter wheat cultivars. Postepy Ochronie Roslin, 39: 801-804.

Leslie, J. F., K. A. Zeller, S. C. Lamprecht, J. P. Rheeder and W. F. O. Marasas. 2005. Toxicity, Pathogenicity, and Genetic Differentiation of Five Species of Fusarium from Sorghum and Millet. Phytopathology, 95: 275-283.

Liu, B., L. Giesler, T. Jackson-Ziems, S. Wegulo, R. Harveson, K. Korus and R. Klein. 2013. Major Fusarium diseases on corn, wheat and soybeans in 
Nebraska.

Logrieco, A., A. Bottalico, G. Mulé, A. Moretti and G. Perrone. 2003. Epidemiology of toxigenic fungi and their associated mycotoxins for some Mediterranean crops. Epidemiology of Mycotoxin Producing Fungi. Springer Netherlands, pp. 645-667.

Mathur, S. 1990. Summaries of research project 19671988. Danish Govt. Inst. of Seed Path. For Dev. Countries, Denmark, 111.

Mathur, S. 2003. Common Laboratory Seed Health Testing Methods for Detecting Fungi. International Seed Testing Association.

Mittal, R. K. 1983. Studies on the mycoflora and its control on the seeds of some forest trees. I. Cedrus deodara. Canadian Journal of Botany, 61: 197-201.

Naeem, K., S. Anwar, M. Haque, A. Riaz and M. Khan. 2001. Seed-borne fungi and bacteria of rice and their impact on seed germination. Pakistan Journal of Phytopathology, 13: 75-81.

NELSON, P. M. and T. WFO TOUSSOUN. 1983. Fusarium Species: an Illustred Manual for Identification. The Pennsylvania State University.

Niaz, I. and S. Dawar. 2009. Detection of seed borne mycoflora in maize (Zea mays L.). Pakistan Journal of Botany, 41: 443-451.

Ozcelik, S., N. Ozcelik and L. R. Beuchat. 1990. Toxin production by Alternaria alternata in tomatoes and apples stored under various conditions and quantitation of the toxins by high-performance liquid chromatography. International Journal of Food Microbiology, 11: 187-194.

Rahim, S. M. and S. S. Hussain. 2013. Studies on stored grain fungi Part I. Fungi on wheat and rice from Karachi. Pakistan Journal of Scientific and Industrial Research, 11: 375-387.

Raper, K. and D. Fennel. 1965. Aspergillus terreus group. The genus Aspergillus. The Williams \& Wilkins Co., Baltimore, Md.

Sonni, A. 2002. Importance of minerals and trace minerals in human nutrition. Website: www. mgwater. com/imp or. Shtml (15 April, 2004).

Sultana, N. and A. Ghaffar. 2007. Seed-borne fungi associated with bitter-gourd (Momordica charantia Linn.). Pakistan Journal of Botany, 39: 2121-2125.

Yuan, Z. Q., K. M. Old, S. J. Midgley and D. Solomon. 1997. Mycoflora and pathogenicity of fungi present on stored seeds from provenances of Eucalyptus pellita. Australasian Plant Pathology, 26: 195.

Zitter, T. A. and C. DL Thomas. 1996. Compendium of cucurbit diseases. American Phytopathological Society, St. Paul, Minn.(EUA). 